\title{
Evangelios apócrifos y gnosticismo
}

\author{
Xavier Alegre, \\ Centro de Reflexión Teológica, San Salvador, \\ Facultad de Teología de Cataluña, Barcelona.
}

\section{Introducción ${ }^{1}$}

Los movimientos gnósticos, esotéricos, viven hoy un boom. No se trata sólo de una "moda" intelectual, sino que, como ocurrió ya hace casi 2000 años, responde a una experiencia religiosa determinada. La gnosis no es un fenómeno específico de una sola época ${ }^{2}$. Pero es importante que caigamos en la cuenta

1. Una información general sobre la gnosis se puede encontrar en F. García Bazán, Gnosis: la esencia del dualismo gnóstico, Buenos Aires, 1978 (la $1^{\text {a }}$ edición es de 1971); H. M. Schenke, "La gnosis", J. Leipoldt, W. Grundmann (eds.), El mundo del Nuevo Testamento, Vol. 1, Madrid, 1973, pp. 387-431; A. Piñero, J. Montserrat Torrents, F. García Bazán, Textos gnósticos. Biblioteca de Nag Hammadi, Vol. I, Madrid, 1997, pp. 19-117; E. Pagels, Los evangelios gnósticos, Barcelona, 1982; A. Orbe, Estudios valentinianos, Vol. I-V, Roma, 1955-66; Id., Teología de San Ireneo. Comentario del libro V del "Adversus haereses", Vol. I-III, Madrid, 1987; H. C. Puech, En torno a la gnosis. I. La gnosis y el tiempo y otros ensayos, Madrid, 1982; K. Rudolph, "Gnosis: una concepción del mundo de la antigüedad tardía”, Selecciones de Teología 27 (1988) 138-142; U. Bianchi (ed.), Le origini dello gnosticismo. Colloquio di Messina, 13-18 aprile 1966, Leiden, 1970; H. Jonas, Gnosis und spätantiker Geist, 2 vol., Göttingen, 1966; The Gnostic Religion, Boston, ${ }^{3} 1970 ;$ S. Pétrement, Essai sur le dualisme chez Platon, les Gnostiques et les Manichéens, París, 1947; G. Quispel, Gnostic Studies, 2 vol., Estambul, 1974-75.

2. Por eso M. Guerra se pregunta qué conexión hay entre el gnosticismo moderno y el antiguo. “Son realidades con entronque histórico-genético, es decir, a través de una serie de eslabones unidos de modo visible o invisible, una especie de caudal guadiánico o de raíces subterráneas que brotan y rebrotan, o tienen sólo un parecido simplemente fenomenológico, o sea, su coincidencia en unos cuantos temas, rasgos y formas o apariencias sin dependencia directa ni indirecta?", "El gnosticismo antiguo y moderno", Biblia y Fe 22 (1996) 218, cfr. 216-272. 
de que, además, fue muy significativa, precisamente, en los comienzos del cristianismo ${ }^{3}$.

De hecho, parece que las corrientes de pensamiento religioso que podríamos denominar como mínimo "gnostizantes" fueron muy importantes en el entorno donde se formularon algunos de los escritos del círculo joánico ${ }^{4}$ y de las cartas deuteropaulinas ( $c f r$. 1Tim 6, 20; 2Tim 2, 16; Tit 3, 9) $)^{5}$, quizás también en las cartas de Pablo a los Corintios 6 . Pero, sobre todo, en los siglos II y III, tuvieron una gran influencia y una abundante producción literaria. Propiamente, sólo en esta época podríamos hablar de gnosticismo, de acuerdo con la terminología del Coloquio de Mesina (1966), que proponía que reserváramos este nombre tan sólo para los sistemas gnósticos desarrollados, que encontramos sobre todo en los siglos II-III?.

De entrada, conviene tener presente que el nombre de "gnósticos" se debe, según Hipólito (Filósofo 5,1,4), a que el grupo de los denominados "naasenos" (en

3. C. Scholten hace una observación acertada que ayuda a comprender que la gnosis se extendiera fácilmente, antes de que provocara la reacción de las grandes iglesias cristianas. "La Iglesia en el siglo II no ha estructurado todavía una dogmática acabada, sino que está dando los primeros pasos para desarrollar las normas doctrinales que describan y aseguren el núcleo irrenunciable de lo cristiano, qué forma parte de lo cristiano y qué no. Domina un pluralismo de modelos de pensamiento, un impulso reflexivo no controlado, no reglamentado por ninguna instancia superior, al que no sin razón se le compara acertadamente con los experimentos en un laboratorio. Las normas de la ortodoxia no se estructuran sino poco a poco y sólo dentro del debate racional sobre lo verdadero y lo falso. Basílides, Valentín y Marción, para nombrar sólo a algunos importantes, concurren con muchos otros, 'gnósticos' y 'no gnósticos', por el liderazgo de las opiniones teológicas. Justino (que muere alrededor del 165) es el primero que desarrolla, desde la perspectiva de la 'gran Iglesia', un concepto de herejía que permita clasificar las posiciones doctrinales diferentes como desviaciones de una norma alcanzada", "Problemas de la investigación de la 'gnosis': problemas antiguos y nuevos enfoques”, Revista Católica Internacional 21 (1999) 161.

4. Cfr. X. Alegre, El concepto de salvación en las Odas de Salomón. Contribución al estudio de una soteriología gnostizante y sus posibles relaciones con el cuarto Evangelio, Münster, 1977, pp. 451-472; también, "Evangelio según san Juan: un evangelio inculturado", Reseña Bíblica 24 (1999) 23-32.

5. Cfr. T. Söding, "Mysterium fidei. Zur Auseinadersetzung mit der 'Gnosis' in den Pastoralbriefen", Internationale katholische Zeitschrift 26 (1997).

6. Un estudio algo antiguo, pero clásico, sobre esta cuestión es el de W. Schmithals, Gnosis in Korint. Eine Untersuchung zu den Korintherbriefen, Göttingen, 1956; Neues Testament und Gnosis, Darmstadt, 1984; cfr. también K. Berger, "Gnosis/Gnostizismus I", TRE 13 (1984) 523s.

7. Cfr. U. Bianchi (ed.), Le origini dello Gnosticismo, Leiden, 1967, p. XXIX. A pesar de las críticas que esta distinción ha cosechado recientemente, ayuda a entender qué es aquello sobre lo que se está hablando. 
hebreo naas significa "serpiente") "se autodenominaron 'gnósticos', proclamándose como los únicos poseedores del conocimiento (gnosis, en griego) profundo"».

Por otro lado, como indica Manuel Guerra, "parece seguro que la literatura gnóstica fue más copiosa que la ortodoxa o de la Iglesia. Los gnósticos eran los 'intelectuales' a la moda de su tiempo" ". Parece que el gnosticismo ha acompañado a las iglesias cristianas desde los inicios, de manera que se ha podido decir que el "gnosticismo es la sombra de la Iglesia" ${ }^{10}$. Y se le encuentra presente en todas partes muy pronto, en las diferentes regiones del imperio romano.

Los evangelios apócrifos que se han encontrado en Nag Hammadi serían, de hecho, una buena prueba de la importancia de la gnosis y del gnosticismo, en los primeros siglos del cristianismo. En todo caso, los evangelios apócrifos, marcados por el pensamiento gnóstico, nos ayudan a descubrir que las iglesias cristianas fueron ya muy plurales, en los tres primeros siglos del cristianismo ${ }^{11}$. Y nos ayudan a comprender mejor cómo fueron los orígenes de éste.

Sin embargo, sigue siendo hoy un tema todavía debatido cómo se originó la gnosis y el gnosticismo ${ }^{12}$. De hecho, se han encontrado textos que parecen presuponer que existió una gnosis no cristiana. Hay especialistas que defienden que no se trata de un fenómeno que apareció sólo con el cristianismo y que se deriva de él, pues hay textos que no están marcados por el cristianismo. Y un autor tan significativo como R. Bultmann defendió que, además de ser anterior al cristianismo, influyó en el Nuevo Testamento, sobre todo en Juan ${ }^{13}$. Otros, en cambio, ponen

8. Los distintos grupos recibieron, en principio, diversas denominaciones, según el nombre de su líder (valentinianos, basilidianos, setianos, etc.) o según alguna de sus creencias fundamentales. Por ejemplo, si dan un culto especial a la serpiente, reciben el nombre de "ofitas" (les viene de ophys, que significa "serpiente" en griego) o el de "naasenos" (en hebreo "serpiente" se denomina naas).

9. Op. cit., p. 218. La mayoría de los escritos gnósticos se pueden leer ahora en español, en la obra editada por A. Piñero, J. Montserrat Torrents, F. García Bazán, Textos gnósticos, Biblioteca de Nag Hammadi, Madrid, 1997-2000 (3 vol.). En alemán se puede consultar W. Foerster, Die Gnosis: 1. Zeugnisse der Kirchenväter; 2. Koptische und mandäische Quellen, Zürich-Stuttgart, 1969-1971; R. Haardt, Die Gnosis. Wesen und Zeugnisse, Salzburg, 1967.

10. J. Van Ort, “New Light on Christian Gnosis”, Louvain Studies 24 (1999) 22.

11. Y lo fueron incluso según el testimonio de los escritos del Nuevo Testamento. $C f r$. R. E. Brown, Las iglesias que los apóstoles nos dejaron, Bilbao, 1986.

12. Cfr. C. Colpe, "Gnosis II/Gnostizismus" RAC 11 (1991) 541-545.639-654.

13. Si R. Bultmann defendía que el autor del evangelio de Juan era un gnóstico que se había convertido al cristianismo, que más tarde será considerado como "ortodoxo", E. Käsemann llega a afirmar en su libro El testamento de Jesús (Salamanca, ${ }^{2} 1983$ ) que el autor sería un cristiano gnóstico, pero que, providencialmente, al redactar la lista de los libros canónicos del Nuevo Testamento, las grandes iglesias no habrían caído en la cuenta de ello y lo canonizaron. 
como objeción que difícilmente pudo ser un fenómeno no cristiano y llegan a dudar, incluso, de que pudiera ser un fenómeno anterior al cristianismo ${ }^{14}$.

A la búsqueda, pues, de sus orígenes, los especialistas han hablado de sus posibles raíces persas ${ }^{15}$ o mesopotámicas. Pero otros han visto en él más bien la influencia de la sabiduría judía ${ }^{16}$ como tránsito hacia la gnosis y el gnosticismo (y un testimonio de esta interrelación entre la gnosis y el judaísmo lo encontraríamos en las Odas de Salomón). La cuestión de los orígenes es, por tanto, una cuestión debatida entre los especialistas. Pero no intentaré aquí responderla, pues no es el objeto de este artículo.

\section{Los evangelios apócrifos gnósticos}

Cuando hablamos de evangelios apócrifos gnósticos nos estamos refiriendo a obras que llevan unos títulos tan significativos como Evangelio de Tomás ${ }^{17}$, $E_{\text {Evangelio de Felipe }}^{18}$, Evangelio de María (Magdalena) ${ }^{19}$, Evangelio de Judas ${ }^{20}$,

14. Cfr. E. M. Yamauchi, Pre-Christian Gnosticism, London, ${ }^{3} 1983$; S. Pétrement, Le Dieu séparé. Les origines du gnosticisme, París, 1984; también M. Hengel, "Die Ursprünge der Gnosis und das Urchristentum“, en J. Adna, S. F. Hafermann, O. Hofius (eds.), Evangelium, Schriftauslegung, Kirche, Göttingen, 1997, pp. 190-223.

15. Cfr. R. Reitzenstein, Das iranische Erlösungsmysterium, Bonn, 1921. Aunque este autor exagera quizás el papel de este influjo, hay ciertamente influencias iranianas en el dualismo y en la soteriología gnósticas ( $c f r$. R. McL. Wilson, The Gnostic Problem, London, ${ }^{2}$ 1964, pp. 172-155); cfr. también Piñero, Montserrat, op. cit., pp. 91-93.

16. O de la apocalíptica y del judaísmo, en general. Cfr. R. McL. Wilson, "Gnosis/Gnostizismus”, TRE 13 (1984) 537-540; cfr. también Piñero, Montserrat, op. cit., p. 93s.

17. La estrella entre estos evangelios gnósticos, porque contiene 114 palabras (logia) de Jesús, algunas de las cuales se parecen a las que se encuentran en los sinópticos y porque, según algunos especialistas, provendrían de una tradición oral de las palabras de Jesús, que sería independiente y quizás anterior a las tradiciones que recogen los sinópticos. Otras palabras, en cambio, parece que están claramente influenciadas por corrientes gnósticas. Se puede encontrar una amplia información sobre la investigación a propósito de este evangelio (datos, relaciones con los evangelios canónicos, etc.) en F. T. Fallon, R. Cameron, "The Gospel of Thomas. A Forschungsbericht and Analysis", ANRW II 25.6 (1988) 4196-4251.

18. Una colección de extractos, sacada sobre todo de una catequesis sacramental cristiana gnóstica. Cfr. WW. Isenberg, "Introduction: The Gospel of Philip", en J. M. Robinson (ed.), The Nag Hammadi Libray, San Francisco, 1988, p. 141.

19. Se ha hecho notar sus semejanzas con otras obras gnósticas que podrían haber llevado también el nombre de evangelio y que contienen diálogos con Jesús resucitado. Me refiero a obras como el Apócrifo de Juan, el Diálogo del Salvador o el Apócrifo de Santiago.

20. Un texto que pone de manifiesto un desprecio notable del cuerpo, algo que, como veremos, es típico de la gnosis. 
Evangelio de la Verdad ${ }^{21}$ o Evangelio de los Egipcios ${ }^{22}$. De todos ellos se hablará específicamente a lo largo de nuestras jornadas. Evidentemente, ninguna de estas obras ha sido escrita por los apóstoles, a los que la obra correspondiente es atribuida, o por María Magdalena. Pero se les da este título imitando lo que, también en el siglo II, se hizo con los evangelios canónicos, para indicar así la autoridad del escrito en cuestión.

\subsection{Cuestiones debatidas a propósito de los evangelios apócrifos gnósticos}

Una de las cuestiones complicadas que nos plantean estos escritos es la de poder fechar exactamente cuándo aparecieron los evangelios que denominamos apócrifos y que están marcados, en mayor o menor grado, por el pensamiento gnóstico. ¿Son anteriores, contemporáneos o posteriores a los cuatro evangelios que denominamos canónicos y que fueron escritos entre los años 70 y 100 ? Y si son posteriores, como parece que lo son, nos hemos de preguntar, entonces, si las tradiciones que utilizan dependen o no de los evangelios canónicos. Es decir, nos hemos de preguntar si estas tradiciones son anteriores, contemporáneas o, al menos, independientes de estos evangelios.

Según sea la respuesta que demos a estas preguntas, nos tendremos que preguntar entonces si estos evangelios apócrifos son tan significativos para el conocimiento del "Jesús histórico" como lo pretenden muchos representantes de la denominada "Tercera investigación" (Third Quest)"23.

Por otro lado, el hecho de que estos evangelios (si prescindimos de pequeños fragmentos en griego), en buena parte, sólo se hayan encontrado en traducciones coptas del siglo IV y que no dispongamos de un número suficiente de manuscritos de cada obra, de manera que podamos garantizar la fidelidad de los encontrados a los originales, dificulta aún más la evaluación de estos textos.

Otra cuestión que nos hemos de plantear también es hasta qué punto los evangelios marcados por la gnosis, que hemos encontrado en Nag Hammadi,

21. Más que un evangelio, parece un sermón (al estilo de la carta a los Hebreos), que va alternando exposición y exhortación.

22. Quizás es el que más se parece a los evangelios canónicos, pero describe la salvación de un modo gnóstico. Un Set celestial, hijo de Adamas, es presentado como el padre y el salvador de los seres humanos, revistiendo durante un tiempo el vestido de Jesús para poder realizar la salvación de sus hijos. Cfr. A. Böhlig, F. Wisse, "Introduction: The Gospel of the Egyptians", en Robinson (ed.), Nag Hammadi, p. 208.

23. Personalmente, comparto la opinión de R. E. Brown, quien, en una crítica de la obra editada por J. Robinson, The Gnostic Gospels, sostiene que de los escritos descubiertos en Nag Hammadi, "no podemos aprender ningún nuevo dato verificable sobre el ministerio histórico de Jesús; en ellos sólo podemos encontrar unas pocas palabras de Jesús que puedan haber sido suyas", "The Gnostic Gospels", The New York Times Book Review, 23 de enero de 1980, p. 3. 
merecen realmente el nombre de evangelio, tal como lo afirma la tradición que los ha hecho llegar hasta nosotros. Pues los evangelios canónicos, a pesar de tener bastantes diferencias entre ellos, tienen en común (sobre todo los sinópticos, pero también Juan) que narran la vida y las palabras de Jesús, situándolas en el marco de su vida. Una vida que, por su opción a favor de los pobres y de los que tenían la vida amenazada y por denunciar los poderes fácticos que los oprimían, lo llevó a la cruz y a la resurrección. Ésta fue la gran aportación de Marcos, quien dio el nombre de evangelio a su obra. Su aportación fue tan genial que los demás sinópticos incorporaron la obra de Marcos a su texto. Y en el caso de Juan, hay que afirmar, como mínimo, que éste lo imitó, en el marco que dio a su obra.

Nada de esto encontramos en los evangelios apócrifos, influenciados por la gnosis. Son mucho más diversos entre ellos, en cuanto a sus contenidos. Y no sitúan las palabras de Jesús (que en ellos a menudo no son públicas, sino "secretas", reveladas a un destinatario privilegiado de estas palabras, que puede ser un apóstol, como Tomás ${ }^{24}$, o María Magdalena, etc.) en el marco de la vida que lo llevó a la cruz.

Pero antes de cuestionar el título que llevan ahora, no podemos olvidar el significado de la palabra evangelio para Pablo ( $c f r$. Rom 1, 3-4.16-17) y que podía tener, por tanto, en el cristianismo primitivo. Se trata de un significado que Lutero recuerda, en el prólogo a su interpretación de la Primera Carta de Pedro:

Ahora bien, "evangelio" significa, sencillamente, un sermón y un grito sobre la gracia y la misericordia de Dios, merecida y conseguida por Cristo, el Señor, con su muerte. El evangelio no es lo que encontramos en libros, escrito con letras, sino más bien un sermón oral y una palabra viva, y una voz que resuena en todo el mundo y se alza públicamente, de tal manera que se escucha en todas partes (Weismarer Ausgabe, vol. 12 [1891] p. 259).

Por eso, H. J. Klauck ${ }^{25}$ subraya, con razón, que tanto la tradición oral kerigmática, como los textos de los evangelios, permanecieron referidos la una a los otros de modo dinámico, siendo precisamente el texto de Marcos 1, 1 una etapa importante, pero no exclusiva, de este proceso. Esto explicaría que se atrevieran a dar el nombre de evangelio a unos textos nuevos, que querían dar fundamento a la nueva comprensión del cristianismo de los grupos gnósticos.

24. Esto es lo que supone, por ejemplo, el final del dicho 13 del Evangelio de Tomás: "Cuando Tomás volvió hacia sus compañeros le preguntaron: ¿qué te ha dicho Jesús? Tomás les dijo: Si yo os dijera una de las palabras que me ha dicho, cogeríais piedras para arrojarlas contra mí y saldría fuego de las piedras que os consumiría".

25. Cfr. Los evangelios apócrifos. Una introducción, Santander, 2006, pp. 315s, que cita el texto de Lutero. 


\section{2. ¿Por qué aparecen estos evangelios?}

Conviene observar que el gnosticismo, no sólo influyó en algunos aspectos del cristianismo, tal como podemos ver, por ejemplo, en el Evangelio de Juan, sino que también es, al menos en algunos de los textos que hemos encontrado, una reacción contra la manera cómo las grandes iglesias cristianas encarnaban la fe. Esta fe, que después será considerada como "ortodoxa” por las iglesias testimoniadas en el Nuevo Testamento, encontró su testimonio más preclaro en los cuatro evangelios denominados canónicos $^{26}$.

A pesar de que la reacción gnóstica contra el cristianismo, representado por las iglesias que se apoyaban en los evangelios canónicos y las cartas atribuidas a Pablo (sobre todo las que se encuentran testimoniadas en las cartas pastorales) es, a menudo, desmesurada, sus críticas son, con todo, parcialmente legítimas y están bien fundamentadas. Desgraciadamente, ni las grandes iglesias supieron descubrir los puntos positivos que podían tener las críticas de estos grupos, ni ellos hicieron ningún esfuerzo especial por dialogar con las grandes iglesias cristianas.

Esto supuesto, quiero destacar tres cosas contra las cuales reaccionaron, en mayor o menor grado, los grupos gnósticos, pues siguen siendo de actualidad.

\subsubsection{Una protesta contra una excesiva jerarquización de la Iglesia}

La protesta está motivada por el hecho de que las iglesias cada vez más toman, como punto de referencia de su funcionamiento y gobierno, la estructura patriarcal del imperio romano. Es verdad que la mayoría de los escritos del Nuevo Testamento no manifiestan todavía este talante autoritario. Pero algunos de ellos, como las denominadas cartas pastorales, atribuidas a Pablo, revelan el inicio de unas tendencias patriarcales, que irán tomando fuerza en las Iglesias cristianas. Las encontraremos aún más claramente testimoniadas en Ignacio de Antioquía. Y ganarán en importancia, más tarde, en el debate con el montanismo. Es decir, son tendencias que, por tanto, toman fuerza en la época en la cual se originaron, si no todos (se discute el caso del Evangelio de Tomás), sí, al menos, la mayoría de los evangelios gnósticos.

Éstos cuestionan, entonces, la pretensión de las grandes iglesias de gozar en exclusividad de la autoridad apostólica para administrar la experiencia religiosa (cristiana) y para interpretar el legado del Señor Jesús, devaluando, en consecuencia, el papel y la corresponsabilidad de toda la comunidad. No es, por tanto,

26. Cfr. A. N. Terrin, "Despertar religioso: nuevas formas de religiosidad", Sel Teol 32 (1993) 127-136; Editorial de La Civilta Cattolica, "'New Age': un nuevo reto para el cristianismo", ibíd., 140-146; A. González Dorado, "La Iglesia ante el fenómeno social de las sectas", ibíd., 147-151. 
ninguna casualidad que la gnosis y el gnosticismo florecieran, precisamente, cuando la estructuración jerárquica de las iglesias se va consolidando, en su triple dimensión de obispos, sacerdotes y diáconos. Para las iglesias, que aceptan como normativos sólo los evangelios canónicos, sólo estas personas —en cuanto legitimadas por la sucesión apostólica - son las que pueden garantizar la fidelidad a la tradición original, fundadora del cristianismo.

En cambio, para los gnósticos "la invención creativa original era la marca de todo aquel que se volvía espiritualmente vivo", y "a quienquiera que se limitase a repetir las palabras del maestro se le consideraba inmaduro", ya que "quienquiera que reciba el espíritu se comunica directamente con lo divino" ${ }^{\prime 27}$.

Lo que está en juego, por lo tanto, en la protesta gnóstica cristiana es quién interpreta y administra de modo adecuado y con autoridad la revelación de Jesús de Nazaret que, según el Nuevo Testamento ( $c f r$. Lc 1, 1-4) nos ha llegado inicialmente a través de sus compañeros y compañeras, que lo siguieron desde su actuación pública en Galilea. Para los gnósticos, lo que importa no es tanto la reproducción de la tradición conservada por el círculo de discípulos, cuanto el conocimiento creador. Por esto, según Pagels ${ }^{28}$, la respuesta que dan a esta pregunta Valentín y sus seguidores es la siguiente:

Quienquiera que entre en contacto directo y personal con "El que vive". Arguyeron que sólo la experiencia propia ofrece el criterio último de la verdad, teniendo prioridad ante todo las formas de invención creativa como prueba de que una persona ha pasado a estar espiritualmente viva. Según esta teoría, la estructura de la autoridad jamás puede quedar fijada a un marco institucional: debe seguir siendo espontánea, carismática y abierta.

\subsubsection{Una protesta contra la marginación progresiva de las mujeres en la Iglesia}

Esta marginación empezó a aparecer ya en algún escrito tardío del Nuevo Testamento. A modo de ejemplo, recordemos lo que se lee en la primera carta a Timoteo $(2,11-15)$ :

La mujer oiga la instrucción en silencio, con toda sumisión. No permito que la mujer enseñe ni que domine al hombre. Que se mantenga en silencio. Porque Adán fue formado primero y Eva en segundo lugar. Y el engañado no fue Adán, sino la mujer que, seducida, incurrió en la transgresión. Con todo se salvará por su maternidad mientras persevere con modestia en la fe, en la caridad y en la santidad.

27. E. Pagels, Los evangelios gnósticos, Barcelona, 1982, p. 59.

28. Ibíd. 
Algunos autores creen que ya en Pablo encontramos también estas tendencias marginadoras de la mujer. Pero se trata de una cuestión hoy debatida entre los especialistas, sobre todo si, como parece, el texto de Primera Corintios 14, 34-35 $5^{29}$ no es de Pablo y si se tiene en cuenta Romanos 16, donde se puede ver que Pablo reconoce el liderazgo espiritual de muchas mujeres que se encuentran en Roma, cuando escribe la carta. Entre ellas está Junia, la mujer que fue apóstol (cfr. Rom 16, $\left.7^{30}\right)$.

La mayoría de los gnósticos ${ }^{31}$, en cambio, inspirándose quizás en el Evangelio de Juan, en el cual las mujeres desarrollan un claro papel teológico y pastoral, les da un gran protagonismo eclesial (en algunos grupos, se exalta sobre todo la figura de María Magdalena, la receptora extraordinaria de muchas de las revelaciones de Jesús).

Después de decir todo esto, Mariam permaneció en silencio, dado que el Salvador había hablado con ella hasta aquí. Entonces Andrés habló y dijo a los hermanos: "Decid lo que os parece acerca de lo que ha dicho. Yo, por mi parte, no creo que el Salvador haya dicho estas cosas. Estas doctrinas son bien extrañas". Pedro respondió hablando de los mismos temas y les interrogó acerca del Salvador: “¿Ha hablado con una mujer sin que lo sepamos, y no manifiestamente, de modo que todos debamos volvernos y escucharla? ¿Es que la ha preferido a nosotros?”. Entonces Mariam se echó a llorar y dijo a Pedro: "Pedro, hermano mío, ¿qué piensas? ¿Supones acaso que yo he reflexionado estas cosas por mí misma o que miento respecto al Salvador?".

Entonces Leví habló y dijo a Pedro: "Pedro, siempre fuiste impulsivo. Ahora te veo ejercitándote contra una mujer como si fuera un adversario. Sin embargo, si el Salvador la hizo digna, ¿quién eres tú para rechazarla? Bien cierto es que el Salvador la conoce perfectamente; por esto la amó más que a nosotros" (Evangelio de María 17-18).

29. Cfr. A. M. Dubarle, "Paul et l'antiféminisme", Revue des Sciences Philosophiques et Théologiques, 60 (1976) 261-279 (condensado en Selecciones de Teología, 17 [1978] 87-96).

30. Cfr. X. Alegre, "Junia, ¿una mujer apóstol (Rm 16, 7)?”, en Memoria subversiva y esperanza para los pueblos crucificados, Madrid, 2003, pp. 335-351.

31. Hablo aquí de la mayoría, porque la postura de los gnósticos es a veces un poco ambigua en su relación con las mujeres, como reconoce E. Pagels, en Gnosticism and New Testament, Minneapolis, 1993, p. 167. Es antifemenino el tratado gnóstico no cristiano Zostriano: "No os bauticéis en muerte ni os entreguéis a quienes son inferiores a vosotros como si fueran mejores; escapad de la locura y la cadena de la feminidad, y elegid para vosotros la salvación de la masculinidad" (n. 131; NH I, p. 279). 


\subsubsection{Una protesta contra una respuesta superficial al problema del mal}

El hecho de que haya tanto mal en este mundo, sobre todo entre los inocentes, resulta en el fondo muy difícil de explicar, también para los creyentes. Esto llevó a los gnósticos a pensar que este mundo no era obra del Dios bueno y que el mal escapa a la posibilidad de su intervención, porque es un Dios lejano, trascendente. No es que ellos den aquí una explicación adecuada del problema. Pero pone de manifiesto que los gnósticos toman conciencia de la dificultad que plantea a los creyentes esta cuestión teológica y que no basta con unas reflexiones superficiales para intentar responderla.

Supuesto que tienen esta concepción tan negativa de la creación, del mundo y de la materia corporal, es obvio que el concepto de salvación adquiera en ellos una dimensión radicalmente nueva, en relación a la manera como la presentan los evangelios canónicos. Es, entonces, específico del gnosticismo la tesis de que la salvación no se adquiere por la redención obtenida por Jesús en la cruz o por la liberación del pecado, sino que se consigue por el conocimiento. Pero no por un conocimiento cualquiera, sino por un conocimiento superior a los sentidos, a la razón y a la fe. Un conocimiento, sin embargo, que no poseen todos los mortales, sino tan sólo aquellas personas (las pneumáticas, espirituales) que han sido agraciadas con una chispa de la luz divina, desprendida de Dios y encerrada en la prisión del cuerpo material (la sarx, la carne).

Por eso, puede verse que el logion (dicho) 1 del Evangelio de Tomás tiene resonancias gnósticas:

Éstos son los dichos secretos que Jesús el viviente ha dicho y ha escrito Dídimo Judás Tomás. 1. Y ha dicho: El que encuentre la interpretación de estos dichos no gustará la muerte ( $N H$ II, p. 79).

Se trata de un conocimiento dinámico y experiencial. Por ello, los gnósticos no tienen ningún interés en que quede petrificado en credos estáticos. Por eso, tampoco resulta siempre fácil interpretar su pensamiento.

Sí tienen interés, en cambio, en retornar a la unidad primordial, que existía antes de la "caída" en este mundo (lo veremos más adelante), superando así las diferencias.

Jesús vio a unos pequeños que mamaban. Dijo a sus discípulos: "Estos pequeños que maman son semejantes a los que entran en el Reino". Le dijeron: “Entonces, ¿haciéndonos pequeños entraremos en el Reino?”. Jesús les dijo. "Cuando hagáis de los dos uno y hagáis lo de dentro como lo de fuera y lo de fuera como lo de dentro y lo de arriba cono lo de debajo de modo que hagáis lo masculino y lo femenino en uno solo, a fin de que lo masculino no sea masculino ni lo femenino sea femenino; cuando hagáis ojos en lugar de un ojo y una mano en lugar de una mano y un pie en lugar de un pie, una 
imagen en lugar de una imagen, entonces entraréis [en el Reino]" (Evangelio de Tomás 22; cfr. también el logion 114).

\subsection{Rasgos distintivos de los evangelios apócrifos gnósticos}

De manera resumida podríamos decir que todos estos evangelios gnósticos, a diferencia de lo que ocurre en los evangelios canónicos, estarían marcados por los siguientes rasgos:

1) No valoran el compromiso de Jesús con el Reino de Dios y los pobres, un compromiso esencial en su predicación, sobre todo en los sinópticos.

2) No valoran su encarnación, que lo hizo auténticamente humano, ya que la creación, el mundo material, es visto por ellos como una cosa negativa.

3) No valoran la cruz real, expresión de la entrega de Jesús por amor a la humanidad, hasta dar la vida por salvar a todos los hombres y mujeres (salvación en principio universal)

4) No valoran a menudo el compromiso ético, que implica el seguimiento de Jesús.

5) Valoran, en cambio, muchísimo el conocimiento (la gnosis) privilegiado, elitista, que les proporciona la revelación esotérica de Jesús (en algún texto, es una revelación nueva del Resucitado, que en los evangelios canónicos, en cambio, a parte del hecho de que participa ahora del poder de Dios, no revela nada nuevo que no haya explicado ya en su vida pública).

Lo que hemos visto nos ha ayudado a entender el talante tan distinto que diferencia los evangelios canónicos de los evangelios apócrifos gnósticos. Pero para entender mejor los acentos que poseen estos evangelios es bueno que, en un último paso, intentemos comprender mejor cuáles son los rasgos generales del gnosticismo que influyeron en los evangelios apócrifos.

\section{Rasgos generales del gnosticismo}

\subsection{Introducción}

Para poder situar los evangelios apócrifos en relación con el gnosticismo, quiero recordar, finalmente, cuáles fueron los aspectos generales del gnosticismo. Con todo, hemos de tener presente que esta presentación simplifica un poco las cosas, pues hemos de reconocer que el gnosticismo fue muy plural y que encontramos en él diversas ramas con acentos muy propios ${ }^{32}$. Es importante que

32. A pesar de los muchos textos que se han encontrado y de las numerosas investigaciones que se han hecho, el fenómeno gnóstico sigue siendo muy plural y difícil de encerrar en una síntesis ( $c f r$. Scholten, op. cit., pp. 154s), pues "muchas formas parti- 
subrayemos este aspecto porque, a diferencia del cristianismo, en sus autores no encontramos una conciencia de ser una religión especial, conciencia que sí tienen los que forman parte de las diversas iglesias cristianas.

Markschies ${ }^{33}$ resume así las ideas y motivos que caracterizan la "tipología" de la gnosis:

1. La experiencia de un Dios supremo, situado completamente en el más allá y lejano.

2. La introducción, determinada por ello, entre otras cosas, de ulteriores figuras divinas o la escisión de las figuras existentes en figuras que están más próximas al hombre que el Dios lejano y supremo.

3. La estimación del mundo y de la materia como creación maligna y una experiencia, determinada por ello, por la que el gnóstico se siente extraño con respecto al mundo.

4. La introducción de un propio dios Creador o Asistente, designado según la tradición platónica como "artesano" —en griego: demiourgos - y, en parte, descrito simplemente como ignorante pero, en parte descrito también como malvado.

5. La explicación de este estado, mediante un drama mitológico, en el cual un elemento divino, que desde su esfera cae en un mundo malvado, dormita como chispa divina en una clase de seres humanos y puede ser liberado de allí.

6. Un conocimiento (gnosis) sobre este estado, que sólo puede lograrse mediante la figura de un redentor del más allá, que desciende de una esfera superior y vuelve a ascender a ella.

La redención mediante el conocimiento del hombre "de que Dios (o la chispa) está en él" (TestVer NHC IX, 3 p. 56, 15-20).

Una tendencia (diferentemente marcada) al dualismo, que puede manifestarse en el concepto acerca de Dios, en la oposición entre el espíritu y la materia, en la antropología ${ }^{34}$.

culares, incluso en una ojeada rápida, no se pueden reducir a un denominador común, aunque sean expresión del mismo fenómeno de la 'gnosis'. Si se compara, por ejemplo, el mensaje del Evangelium Veritatis (NHC 1,3) y la teología del 'gnóstico' Justino según Hipp. (Ref. 5, 23-8), se constatará que entre ellos hay más desemejanzas que analogías y, desde luego, no se caerá inmediatamente en la idea de concebir estas dos fuentes como expresión de la misma 'gnosis"'.

33. Op. cit., pp. $37 \mathrm{~s}$.

34. De todos modos, se ha de tener presente lo que, con razón, observan Piñero y Montserrat, en la introducción a su obra Biblioteca de Nag Hammadi I, pp. 39s: "En una 


\subsection{La salvación se obtiene por el conocimiento}

Es específica de la "gnosis" la tesis de que la salvación, como he dicho antes, se obtiene por medio del conocimiento ${ }^{35}$. En el fondo, se trata de un conocimiento de sí mismo, de lo que hay de más profundo (el pneuma, el espíritu), divino, en el propio ser. Como formula bien Guerra ${ }^{36}$ :

consiste en una introspección psicológico-religiosa, a veces con connotaciones "místicas", del hombre en su propia interioridad, generalmente mediante la respuesta a la triple pregunta: “¿De dónde he venido, dónde estoy, a dónde voy?”, o también: "¿Quién era, quién soy, quién seré?”37. Por eso, en el gnosticismo antiguo, la "revelación" es un "mensaje" de lo alto, capaz de "despertar" al "pneumático, espiritual", es decir, al gnóstico, haciéndolo caer en la cuenta de que su "espíritu" es superior a la materia, que no proviene del mundo inferior o material, sino del pleromático o divino, y que a él debe retornar. La "revelación gnóstica" consiste en "experimentar" la dignidad no de la persona humana, sino de uno de sus

gnosis desarrollada el concepto de dualismo metafísico, o de los primeros principios, es en el fondo una contradicción en sus propios términos, porque el Absoluto, objeto de la especulación gnóstica avanzada, rechaza por su misma definición a todo ser que se escape de él [y citan a F. García Bazán, Gnosis. La esencia del dualismo gnóstico, 23].

"Un auténtico dualismo esencial — aunque corresponda probablemente muy bien a los orígenes más remotos de la gnosis, si se acepta la teoría de que sus lejanísimos principios deben verse en la religión indoirania ( $c f r$. posteriormente) - es rarísimo. Para algunos sistemas gnósticos, como el maniqueísmo, existen desde los orígenes dos Principios iguales y contrapuestos, que serían la Luz y las Tinieblas, el Bien y el Mal. El universo, y con él el hombre, proceden de un ataque - motivado por un impulso esencial— de las Tinieblas contra la Luz. Para la mayoría de los sistemas, sin embargo, existe en los orígenes un solo y único principio, léase Uno, Bien, Padre, Trascendencia, etc., que por un complicado proceso engendra indirectamente el principio del Mal, o mejor de la Deficiencia, o del Error, a partir del cual se genera el universo. Esta concepción del todo como un continuo (en proceso de degradación) es de raigambre estoica.

"En algunos grupos, la pugna entre los dos Principios, bueno y perverso, puede darse ya en el ámbito de lo divino. Pare a todos, al menos el cosmos visible y el hombre se ven gobernados por la lucha de esos dos Principios, el Bien y el Mal, la Materia y el Espíritu, la Luz y las tinieblas. En general, los sistemas gnósticos piensan en términos dualísticos sólo 'de tejas abajo', es decir, en el ámbito del universo, de fuera de la divinidad: la materia en la que vive el hombre y su propio cuerpo es la última y perversa escala del ser y se opone al mundo del espíritu. Este pensamiento, secundariamente dualista, se manifiesta en la cosmología, la antropología y la soteriología".

35. Una buena introducción a la soteriología de los gnósticos la podemos encontrar en el artículo de C. Cannuyer, "Une introduction à la sotériologie des gnostiques", Mélanges de Science Religiieuse 55 (1998) 7-31.

36. Op. cit., p. 220.

37. Son la traducción literal de su doble formulación en los textos gnósticos: Excerpta ex Theodoto, 78, 2; Marcos en Ireneo, Adv.Haer. 1,21,5; 1,24,4. 
componentes: el "espíritu", así como la excelsitud de su origen y de su destino pleromáticos. Por ello no dan importancia al contenido objetivo de la revelación divina. Por eso la gnosis es un "conocimiento salvador" en cuanto ese conocimiento es capaz de hacer consciente al espíritu humano de su destino trascendente, de liberarlo de su situación presente en el cuerpo y en el mundo, así como de colocarlo en su situación definitiva tras la muerte.

Por eso, el tratado Zostriano 44 dice que "el tipo humano que se salva es aquel que se busca a sí mismo y a su intelecto y encuentra ambos" (NH I p. 268).

Es en este contexto que podemos comprender ahora mejor el final del dicho 3 del Evangelio de Tomas ${ }^{38}$.

Jesús dijo: Si os dicen vuestros guías: Mirad, el Reino está en el cielo, entonces los pájaros del cielo os precederán. Si os dicen: está en el mar, entonces los peces os precederán. Pero el Reino está dentro de vosotros y está fuera de vosotros. Cuando os lleguéis a conocer, entonces seréis conocidos y sabréis que vosotros sois los hijos del Padre Viviente. Pero si vosotros no os conocéis, entonces vosotros estáis en pobreza y vosotros sois la pobreza (NH II 79-90; cfr. también los dichos 28 y 50).

$\mathrm{O}$ el siguiente texto del Evangelio de la Verdad.

Aquellos cuyo nombre conoció de antemano han sido llamados finalmente, de modo que el que posee el conocimiento es aquel cuyo nombre ha sido pronunciado por el Padre, pues aquel cuyo nombre no ha sido dicho es ignorante. Efectivamente, ¿cómo podrá oír aquel cuyo nombre no ha sido convocado? Porque el que es ignorante hasta el fin es una obra del olvido y será disuelto con él, de lo contrario ¿cuál es el motivo de que estos desgraciados carezcan de nombre y de que no exista para ellos una llamada?

De esta manera el que posee el conocimiento es de lo alto. Si es llamado, escucha, responde y se vuelve hacia quien lo llama para ascender hacia Él. Y sabe cómo se llama. Poseyendo el conocimiento hace la voluntad de quien lo ha llamado, quiere complacerle y recibe el reposo. Su nombre propio aparece. El que llegue a poseer el conocimiento de este modo sabe de dónde viene y a dónde va. Sabe como una persona que, habiendo estado embriagada, ha salido de su embriaguez, ha vuelto a sí misma y ha corregido lo que le es propio (21-22, NH II 150).

38. Es un tema debatido entre los especialistas si el Evangelio de Tomás se puede considerar gnóstico o no. Y en el caso de que se dé una respuesta positiva, hasta qué punto está marcado por las corrientes gnósticas. Una buena información sobre esta cuestión la podemos encontrar en F. T. Fallon y R. Cameron, "The Gospel of Thomas. A Forschungsbericht and Analysis", Aufstieg und Niedergang des Römischen Reiches, II 25, 6 (1988) 4230-4236, que presentan las opiniones de los diferentes especialistas. 
Se trata, pues, de un conocimiento liberador. Pero, una vez hecha esta constatación, nos hemos de preguntar por qué insisten tanto los gnósticos en la importancia del conocimiento liberador, de la gnosis que libera del cuerpo y del mundo creado, material (como explica bien, por ejemplo, el Evangelio de Judas).

Uno de los problemas que más preocupan a los "gnósticos" es, como he indicado antes, el de la existencia del mal y de los males en el mundo. La respuesta gnóstica al problema del mal implica un cierto dualismo, más existencial que metafísico (un dualismo que será muy claro en un estadio evolucionado, como el maniqueísmo, que tanto influyó en san Agustín). Porque para ellos, el Dios supremo es trascendente, lejano, impersonal e inactivo (recibe distintos nombres: Padre, Trascendente, Amorfo, Abismo, Pre-Padre, etc.). Por eso, no interviene ni en la creación de la materia o la formación del mundo, ni en su gobierno, ni en la vida de los seres humanos, ni en la historia de la humanidad. Ni puede intervenir tampoco en ello, pues se contaminaría, se volvería malo, dejaría de ser divino, porque la materia es el mal.

\subsection{Origen del mundo}

¿Cómo se ha originado, por tanto, el mundo $?^{39}$. En la gnosis valentiniana ${ }^{40}$, un día Dios, por una decisión plenamente libre, decide comunicarse por gracia. Entonces, empieza la emisión de los "eones" (períodos de tiempo, de eternidad), una designación genérica de las entidades o personificaciones del ámbito superior o pleromático, que es propio del mundo divino. Cada "eón" procede de la divinidad, por emanación y emparejamiento (masculino-femenino): TheósKháris (Dios-Gracia), Abyssos-Sigué (Abismo-Silencio), Nous-Alétheia (Entendimiento-Verdad), Lógos-Bíos (Palabra-Vida), Ánthopos-Ekklesía (HombreIglesia), hasta llegar a completar, por ejemplo, la "ogdóada" o las treinta parejas de eones. En este proceso, el elemento femenino de la pareja -y, sobre todo, la "madre" $"$ - tiene mucha importancia.

39. Cfr. Guerra, op. cit., p. 222 ss.

40. Un buen resumen de las doctrinas de los setianos lo podemos encontrar en Piñero, Nag Hammadi I 48-52. Sobre las de los valentinianos, cfr. ibíd., 52-59.

41. "En unos la Madre es el Pensamiento del Padre. En otros es Sabiduría o Barbelo en la doble modalidad trascendente y virginal al mismo tiempo que Sabiduría caída, Sophía Prunicos, también Madre de los siete Arcontes. A veces ocupa la cima de la tríada: Padre, Madre e Hijo $c f r$. H. Ch. Puech, En torno a la gnosis... 198-202, que es una herejía cristiana, la de las colíridas (s. II-III y ss.), que la transforma en Dios Padre, Jesucristo y la Virgen María ( $c f r$. M. Guerra, El sacerdocio femenino en las religiones greco-romanas y en el cristianismo de los primeros siglos, Toledo, 1987, 503-12, 557-60), de las cuales tomó Mahoma el concepto y realidad de la Trinidad cristiana según él, presente en el Corán y en el pensamiento posterior islámico", Guerra, Gnosticismo, p. 223, n. 21. 
El conjunto de esas virtualidades constituye el $\pi \lambda$ bo $\omega \mu \alpha$, o sea, "lo llenado, lo todo", emitido en el seno de la divinidad antes del tiempo y del espacio, antes de que fuera hecho el mundo. "Pleroma" comprende el ámbito superior con todos sus seres, una especie de espacio lleno de claridad y vida, en el cual se ve todo lo que hay en él; contrasta con el kénoma (kénon:"vacío" en griego), o sea, "el vacío, la nada", una especie de ámbito sin luz, ni claridad, en el cual nada hay o en el cual nada se ve, aunque haya algo, el mundo inferior, material ${ }^{42}$.

Hay, pues, una especie de "evolución negativa de lo divino" (una especie de degradación ${ }^{43}$. Dentro de la misma divinidad se realiza un proceso que lleva, finalmente, a una ruptura de la cual brotan, a modo de accidente cósmico o caída pecaminosa, que empieza con una serie de emanaciones, el mundo y el ser humano. "La divinidad suprema se conoce a sí misma en la luz, que es ella misma, que irradia y que le envuelve. En ella, Dios ve reflejada como en un espejo su imagen. Esta imagen consigue una existencia independiente y se convierte en un ser nuevo, que se encuentra en un escalón por debajo del Dios supremo, pero que, a la vez, constituye un aspecto de su ser" ${ }^{\prime 4}$.

El Apócrifon de Juan ${ }^{45}$ lo describe así:

El (supremo) se contempla en la luz que lo rodea, que es la fuente de las aguas vivas que se entrega a todos los eones bajo múltiples formas. Él [contempla] su propia imagen reflejada en la fuente del [espíritu] y desea (habitar) en su agua [luminosa], que es la fuente del agua [pura] que lo rodea. Su [Inteligencia (énnoia) entró] en acción y apareció, [irguiéndose] y manifestándose ante él en el [resplandor] de aquella luz.

Ésta es la [potencia] que existe antes que todos ellos, que [procedió] del pensamiento de aquél, la [suprema Inteligencia del todo], luz [semejanza] de luz, potencia [perfecta], imagen del Espíritu invisible, virginal. Ella lo alabó, pues gracias a él había llegado a la existencia. Éste es el primer pensamiento, la imagen de aquél. Ella fue la matriz del todo, pues existió antes que todos ellos, madre-padre, hombre primordial, espíritu santo, el triple varón, la triple potencia, el triple nombre, el andrógino, el eón eterno entre los invisibles, el primer principado.

Este eón, [es decir, Barbeló], pidió al invisible Espíritu virginal que le fuera concedida una presciencia (prógnosis), y el Espíritu accedió. Y cuando hubo [accedido], se manifestó la Presciencia y se irguió junto a la suprema Inteligen-

42. Guerra, Gnosticismo, p. 223.

43. H. J. Klauck habla de una "devolución de lo divino". Cfr. "Gnosis als Weltanschauung in der Antike", Wissenschaft und Weisheit 56 (1993) 7.

44. Ibíd.

45. Se presenta a sí mismo como una revelación secreta. 
cia, la que procede del pensamiento del invisible Espíritu virginal (n. 4-5, NH I 217s).

Así van emergiendo los cinco eones masculinos (jen griego!): Lógos, Querer, Intelecto, Cristo, Autogenerado. Estos forman pareja con los cinco eones femeninos ( $¡$ en griego!) de la madre: Inteligencia, Vida eterna, Prógnosis, Incorruptibilidad y Verdad ( $c f r$. AJ nn. 5-7, NH I 218-220). Todo este proceso de emanación permanece dentro del "Pleroma". Son diferenciaciones dentro de la realidad divina del Dios supremo y no conducen al origen de algo que sea totalmente diferente y, por tanto, no llevan al origen del mundo.

El mundo material no es, entonces, obra de Dios, sino del Demiurgo y de la Sabiduría. Y es, por tanto, malo. El Demiurgo recibe nombres distintos, según las escuelas (Arconte, Yaldabaot, Saclas, Samael), y es identificado, a menudo, con el Dios del Antiguo Testmamento y contrapuesto al "Dios bueno", supremo (el del Nuevo Testamento, aunque Éste ni nos ha creado, ni nos ha salvado a través de la cruz de Cristo). Este Demiurgo

para hacer los seres materiales realiza las adecuadas mezclas de las formas corporales, que el eón Logos había preparado en la sustancia eónica femenina: Sophia = "Sabiduría", como el pintor que no coge nada de lo pintado, sino sólo las formas. Por tanto todos los seres cósmicos constan de una realidad material, conformada de acuerdo con su respectiva forma-idea preexistente en Sabiduría, que es el eón último del ámbito pleromático. Según el mito de los valentinianos, etc., la Sabiduría, el eón más alejado de la divinidad, ansió aprehender al Infinito, pero en su intento, desde el borde de lo pleromático, se esforzó tanto y lo ansió tan apasionadamente que fue expulsada del pleroma por no ser capaz de dominar su pasión. Sabiduría cayó fuera del pleroma en el kénoma o "vacío". De esta su situación pecaminosa, mala, del mal, brotó el mundo inferior, material, mediante la acción del Demiurgo. Por eso la materia, el mundo, lo material es malo, el mal, y Dios no puede actuar ni intervenir en ello ${ }^{46}$.

Como indica el Apócrifo de Juan, el mundo (y el mal) se originaron, entonces, por culpa de la Sabiduría:

La Sabiduría, que era un eón, concibió en su interior un pensamiento, una reflexión acerca del Espíritu invisible y de la presciencia. Deseó manifestarse en una imagen salida de sí misma sin el querer del Espíritu, que no lo consentía, y sin su consorte, que no daba su aprobación. Y aunque no lo consentía su personificación masculina, y sin haber obtenido su acuerdo, y a pesar de haberlo premeditado sin el consentimiento del Espíritu y de no contar con el acuerdo (de su parte masculina), ella se hizo adelante. Puesto que había

46. Guerra, Gnosticismo, p. 224. 
en ella una potencia invencible, su pensamiento no permaneció inactivo, y a partir de ella se manifestó una obra imperfecta y distinta de su forma, pues la había producido sin su consorte. No se parecía en nada a la figura de su madre, sino que tenía otra forma.

Una vez hubo visto la obra deseada, ésta se transmutó en la figura de un extraño dragón con rostro de león, de ojos resplandecientes como relámpagos. Lo arrojó lejos de ella y de aquel lugar a fin de que no lo viera ninguno de los inmortales, pues lo había creado en ignorancia. Lo envolvió en una nube luminosa y (lo) colocó en un trono en medio de la nube para que nadie lo viera excepto el Espíritu Santo, que es llamado "la madre de los vivientes". Y le puso por nombre Yaltabaot ${ }^{47}$.

Éste es el primer arconte. Recibió de su madre una gran potencia, y se alejó de ella y abandonó los lugares en los que había sido creado. Se robusteció y creó para sí otros eones resplandecientes de fuego luminoso. Allí se halla todavía (nn. 9-10, NH I 221s).

Las ideas fundamentales del mito gnóstico (una formulación muy típica de este mito la podemos encontrar en el denominado Himno de la perla ${ }^{48}$, que utiliza las imágenes del olvido y de la fuerza despertadora de la revelación ${ }^{49}$ para indicar cómo el Hijo, prisionero en este mundo, toma conciencia de pertenecer al mundo de arriba), las podemos leer en el Apócrifo de Juan ${ }^{50}$, cuyo original es, probablemente, del siglo II. En este escrito, el Señor Resucitado revela a Juan "los misterios y las cosas escondidas en el silencio" (n. 1, NH I 215). Comienza con la revelación del Padre y Dios supremo, que es explicado con unas características que son típicas de la teología negativa y que excluyen que Él pueda ser el creador del mundo. Y revelan una concepción dualista de la realidad.

Es el verdadero [Dios] y Padre del todo, [el espíritu invisible] que está por encima [del todo], el que existe en la incorruptibilidad, el que se halla en una pura luz que ninguna [mirada] puede sostener. Puesto que es el [espíritu] invisible, no conviene (pensarlo) como un Dios o algo parecido, pues es más que un dios, ya que nadie hay por encima de él, ni nadie lo domina.

47. Significa probablemente "generador de potencias".

48. El texto en español lo podemos encontrar en García Bazán, Gnosis, pp. 307-313.

49. Es lo que indica Jesús en el Evangelio de Tomás 28: "Jesús dijo: Me he mantenido en medio del mundo y me he manifestado a ellos en carne. Los he encontrado a todos ebrios. No he encontrado a ninguno de ellos sediento, y mi alma se ha apenado por los hijos de los hombres, pues están ciegos de corazón y no ven claramente que han venido al mundo vacíos. Buscan de nuevo salir del mundo vacíos; pero ahora están ebrios. Cuando vomiten su vino, entonces se convertirán” (NH II 85).

50. Cfr. NH I 215-236. 
Pues nada existe antes de él, ni él tiene necesidad de otras cosas. No necesita vida, pues es eterno. No tiene necesidad de nada, porque es ya imperfectible, de modo que no tiene ninguna carencia que lo haga perfectible, antes bien en todo momento es una realidad perfecta y luminosa.

Es [indefinible], porque nadie lo [precede] para poderlo definir. Es inescrutable, porque nadie lo precede para [poderlo escrutar]. Es inconmensurable, porque nadie [lo precede para poderlo medir]. Es [invisible, porque] nadie lo ha visto jamás. Es un eterno que existe eternamente. Es [inexpresable] porque nadie lo abarca para poderlo expresar. Es innominable, porque [nadie lo precede] para poderlo nombrar (nn. 2-3, NH I 216s).

Como observa Klauck ${ }^{51}$, "nosotros tenemos ahora un Demiurgo, que se ha independizado y que empieza a fabricar un mundo propio. Los poderes que ahora se originan, son denominados Eones o Arcontes, también ángeles o Reyes. Entre otras cosas, Yaltabaot constituye siete reyes como señores sobre los siete cielos inferiores (en total hay en esta imagen del mundo diez cielos, con el Pleroma que se encuentra en el noveno y décimo cielo, con el octavo cielo que sirve de transición y los siete cielos inferiores, que son idénticos con las esferas de los planetas y que sirven de campo de acción de las creaturas demoníacas del creador del mundo)".

En esta contexto, podemos entender por qué para el Apócrifo de Juan es tan problemática la creación del Demiurgo:

Estableció también siete reyes, uno para cada firmamento del cielo, sobre la hebdómada celestial, y cinco sobre las profundidades del abismo para que reinaran. Y les repartió su fuego, aunque no los dotó del poder luminoso que había recibido de su madre, pues era una tiniebla ignorante.

Cuando la luz se mezcló con la oscuridad indujo en la oscuridad una iluminación. Cuando la oscuridad se mezcló con la luz, la luz se oscureció, y ya no hubo luz ni oscuridad, sino una cosa débil. El arconte débil tiene tres nombres. El primer nombre es Yaltabaot, el segundo es Saclas, el tercero es Samael. Es un ser impío repleto de necedad. Dijo en efecto: "Yo soy dios y no hay otro dios fuera de mí". Con lo cual se mostró ignorante de su fundamento, el lugar de donde procedió (n. 11, NH I 223).

De todos modos, este Arconte, no es sólo degeneración, pues procede de la Sabiduría. En él se encuentran también partes del Espíritu, de la Luz, que se encontraba inicialmente en el Pleroma. Estos elementos anhelan, obviamente, retornar al Pleroma, en cuanto toman conciencia de su situación caída. Esto da paso, en el mito, a la explicación del origen del ser humano (se reinterpreta

51. Op. cit., p. 9. 
gnósticamente el mito que encontramos en Génesis 2-3) y a la soteriología propia del movimiento gnóstico.

Ante esta situación, y para contrarrestar la equivocación de la Sabiduría, el Dios supremo vuelve a intervenir y así se origina el ser humano.

Cuando la madre se percató de la imperfección del [aborto] de la oscuridad, comprendió que su consorte no había estado en armonía con ella. Se arrepintió, y rompió en un gran llanto. Los (eones) de todo el Pleroma percibieron la amargura de su arrepentimiento y pidieron un socorro para ella al invisible Espíritu virginal. El Santo Espíritu accedió y derramó sobre ella un don procedente de todo el Pleroma. Su consorte no se había acercado a ella, pero entonces se le aproximó por medio del Pleroma a fin de rectificar su deficiencia (nn. 13-14, NH I 224).

Es desde esta perspectiva que podemos entender ahora por qué es tan importante para el gnóstico el conocimiento liberador de quiénes somos, en el núcleo más profundo de nuestro ser (los gnósticos lo denominan Pneuma, Espíritu). Y, consecuentemente, de dónde hemos caído y a dónde hemos de retornar, liberándonos del cuerpo material, si queremos participar del pleroma. Entonces se logra el reposo (la anápausis), pues si la situación del espíritu en el mundo era comparada al sueño, a la borrachera, y esto comportaba inquietud, la salvación es comparada a la tranquilidad, al reposo, que es la consecuencia de haber retornado al Pleroma.

En esta concepción, no es necesario que el Salvador se haya encarnado realmente. Supuesto que el cuerpo material es algo negativo, basta con que tenga una apariencia humana para poderse comunicar a los gnósticos, de modo que con su llamado los despierte del sueño que los tiene privados del conocimiento. Por eso, no nos ha de sorprender que algún texto, como el del Evangelio de Felipe nn. 56-57 (NH II 29), parezca doceta, pues atribuye una realidad exclusivamente espiritual a la carne y sangre de Cristo.

Algunos temen resucitar desnudos. Por ello desean resucitar en la carne. Y no saben que los que portan la carne son los que están desnudos. Aquellos que [son capaces] de desnudarse, son precisamente los que no están desnudos. "La carne y la sangre no heredarán el reino de Dios". ¿Cuál es la que no heredará? La que portamos encima. ¿Y cuál es, en cambio, la que heredará? La perteneciente a Jesús y su sangre. Por ello dijo: "El que no come mi carne y bebe mi sangre no tiene vida en él". ¿Qué (carne) es (ésa)? Su carne es la palabra, y su sangre es el Espíritu Santo. Quien ha recibido estas cosas tiene alimento, y tiene bebida y vestido.

Notemos, finalmente, que en esta manera de concebir la salvación, la muerte de Jesús en la cruz no tiene por que ser real necesariamente, ni tener un signi- 
ficado especial liberador, redentor del pecado, entendido éste éticamente, ni por qué comportar un alcance universal.

\section{Conclusión}

Los evangelios apócrifos (los evangelios de Tomás, Felipe, María Magdalena, Judas, Pedro y Nicodemo) no son, como he indicado antes, tan antiguos como los evangelios canónicos (esto vale incluso para el Evangelio de Tomás, aunque es verdad que este evangelio puede haber recogido tradiciones orales antiguas, independientes de los evangelios canónicos).

En muchos de ellos - y también en textos cono el Evangelio de la verdad, o el Apócrifo de Juan-, encontramos claramente el influjo del gnosticismo (o, al menos, el de la gnosis), lo cual explica muchas de las diferencias entre estos evangelios y los canónicos. Como hemos visto, están llenos de elementos mitológicos, porque, como muy bien indican A. Piñero y J. Montserrat,

la gnosis utiliza abundantemente la mitología ante la, a menudo, imposibilidad para el ser humano de expresar en un lenguaje racional ideas o conceptos que lo trascienden. El mito es la representación poética de unos conocimientos que se abren a la salvación y tiene múltiples variaciones ${ }^{52}$.

Destaca también en estos evangelios su talante más bien elitista, que se aleja mucho de lo que fue la vida de Jesús, tal como nos la cuentan los evangelios canónicos, mucho más comprensibles para la gente sencilla ( $c f r$. Mt 11, 25-30). Es propio de los apócrifos gnósticos, como hemos visto, que la salvación se obtiene por el conocimiento, un conocimiento que comporta cierto desprecio del cuerpo y de la creación. Difícilmente estos escritos conservan tradiciones propias de Jesús. O, en todo caso, no aportan conocimientos nuevos, que puedan resultar relevantes al lado de los que nos aportan los sinópticos.

Pero sí resultan una aportación preciosa para poder conocer mejor el significado del cristianismo y de las dimensiones bastante plurales que éste, tuvo en sus primeros siglos.

De todos modos, nos podemos preguntar, al concluir estas reflexiones, si estos evangelios apócrifos son, como algunos especialistas han afirmado ( $\mathrm{y}$, sobre todo, la propaganda mediática, poco seria desde el punto de mira de la ciencia), unas reproducciones realmente más fieles de lo que fue la vida de Jesús que las que nos ofrecen los evangelios canónicos.

Históricamente, nos consta que la vida concreta de Jesús lo llevó a morir en la cruz, condenado como terrorista, por las autoridades políticas de Roma. Esto

52. En la introducción al primer volumen de su obra Biblioteca de Nag Hammadi, Vol. I, p. 39. 
parece un hecho histórico incuestionable. Por esto, me parece que la respuesta a la pregunta de quién presenta más fielmente, desde el punto de mira de la historia, la vida y las palabras de Jesús, si los evangelios canónicos o los gnósticos, ha de ser más bien que son los evangelios canónicos, a pesar de estar muy marcados por la fe de los discípulos. Pues si Jesús hubiera tenido y vivido la espiritualidad que le atribuyen los evangelios gnósticos, difícilmente hubiera terminado tan pronto en una cruz, condenado por los poderes políticos, económicos y religiosos, que dominaban su mundo, un mundo que, como el nuestro, estaba dominado por la injusticia.

Ésta es una de las razones principales por las cuales pienso que los evangelios canónicos son mucho más fieles a lo que fue la vida y el proyecto de Jesús de lo que lo son los evangelios apócrifos.

Pero es incuestionable, también, que los evangelios apócrifos nos permiten conocer mucho mejor el pluralismo de las iglesias cristianas, en los primeros siglos del cristianismo. En este sentido, nos conviene tomar conciencia de que estos escritos gnósticos enriquecen mucho nuestros conocimientos de esos primeros siglos. 